\title{
Responsibility Sharing or Shifting? "Safe" Third Countries and International Law
}

\author{
MiChelle Foster
}

\section{Abstract}

This article assesses the legality at international law of "protection elsewhere" policies, that is, policies whereby responsibility for refugees is transferred between states such as in the US-Canada Safe Third Country Agreement. An analysis of the operation of such policies in Europe, Australia, and North America raises serious concerns about the ability of such schemes to uphold their aims and objectives in conformity with international law. The paper concludes by recommending that states reconsider the utility and legality of such schemes with a view to developing policies that genuinely address the need for responsibility sharing.

\section{Résumé}

Cet article évalue la légalité en droit international des politiques dites "protection ailleurs", $c$. $-\grave{a}-d$. les politiques sous le couvert desquelles la responsabilité envers les réfugiés est transférée entre états, comme c'est le cas avec l'Entente entre le Canada et les États Unis sur les tiers pays sûrs. Une analyse de l'opération de telles politiques en Europe, en Australie et en Amérique du Nord soulève de sérieuses questions sur la capacité de tels arrangements à respecter leurs buts et objectifs en conformité avec le droit international. Larticle conclut avec la recommandation que les états reconsidèrent l'utilité et la légalité de tels arrangements avec comme objectif le développement de politiques qui répondent réellement au besoin de partage de la responsabilité.

\section{Introduction}

In recent decades many states, particularly in the developed "North," have increasingly relied on a range of deflection, interception, and transfer policies in an attempt to minimize their own obligations towards refugees under the Convention relating to the Status of Refugees (the Refugee Convention).
While many of these occur offshore and are thus difficult to monitor, a more prominent practice has been the formulation of "protection elsewhere" policies such as the adoption of the Agreement Between the Government of Canada and the Government of the United States of America for Cooperation in the Examination of Refugee Status Claims from Nationals of Third Countries (the US-Canada STCA). Agreements such as these apply to refugee applicants once they have successfully avoided or overcome other hurdles constructed by states such as interdiction, carrier sanctions, and deflection policies. In an increasingly large number of states, refugees find that arriving at or entering the territory of a state party is not the end of the journey because they are then informed that they will be sent to a "safe third country"-often, but not necessarily, one in which they transited en route to their final destination. This paper is concerned with the legality of such policies at international law. A protection elsewhere policy, as considered in this paper, refers to a situation in which a state or agency acts on the basis that the protection needs of a refugee should be considered or addressed somewhere other than in the territory of the state where the refugee has sought, or intends to seek, protection. ${ }^{1}$ While sometimes ascribed different labels, including "country of first asylum" or "safe third country," the core legal question remains the same, $v i z$., whether a state may deflect its responsibility under international law by transferring a refugee to another state. ${ }^{2}$ This paper will analyze the US-Canada STCA and its surrounding litigation in some depth, but is not restricted to this particular manifestation of the safe third country concept.

There are various methods by which protection elsewhere policies are implemented. The first is through a formal multilateral assignment scheme such as the Dublin Regulation II, in which the state through which the applicant for asylum entered the EU is responsible for dealing with the application, even if it is lodged in another Member State. The second is a formal bilateral assignment scheme such as the US-Canada 
STCA, which provides that the country of last presence shall examine the refugee status claim of any person arriving at a land border port of entry who makes a refugee claim. ${ }^{3}$ The third is what we might call "unilateral" transfer schemes such as are effected in Australian law via section 36(3) of the Migration Act 1958 (Cth), which excludes from protection a person "who has not taken all possible steps to avail himself or herself of a right to enter and reside in, whether temporarily or permanently, any country apart from Australia."

The key difference between these schemes is that in the case of multilateral and bilateral schemes there is a written agreement between the relevant state parties which, at least theoretically, have reasonably comparable systems of refugee status determination and protection and thus purport to be concerned with the allocation of responsibility between comparable Member States. In these scenarios there is at least a theoretical possibility that "responsibility sharing" could ensure fair and equitable allocation of protection responsibilities as between states. ${ }^{4}$ By contrast, in the case of unilateral removals, where there is not necessarily any readmission or other written agreement, nor any meaningful analysis of the situation pertaining in the "other country," it is more accurate to view these schemes as an attempt to avoid responsibility rather than sharing it fairly as between state parties.

However even the bilateral and multilateral schemes have given rise to serious concerns. First, one might question the responsibility sharing objective given that, for example, in the EU context, the Dublin Regulation does not contain any mechanism for ensuring that responsibility is shared in an equitable manner. As the European Parliament recently noted, it "fails to serve as a burden-sharing mechanism."5 Rather, the experience has been, unsurprisingly, that responsibilities have shifted towards the border states. ${ }^{6}$

Second, divergence of policies and practices even within a theoretically "harmonized" system, such as is established in the EU, ${ }^{7}$ means there is significant inequity in the system which has resulted in an "asylum lottery." For example, the United Nations High Commissioner for Refugees (UNHCR) reports that a Chechen transferred from Austria to Slovakia sees his or her chance of being granted refugee status going from 80 per cent to 0 per cent. ${ }^{8}$ Similarly, the European Council on Refugees and Exiles (ECRE) notes that in 2007 recognition rates for Iraqis varied from 0 per cent in Greece and Slovenia to 87.5 per cent in Cyprus. ${ }^{9}$ Even in the context of the bilateral US-Canada STCA-an agreement between two very similar state parties to the Refugee Convention-there have been many concerns raised as to the adequacy of the US system to fully uphold Article 33 of the Refugee Convention. ${ }^{10}$ Thus, at present, protection elsewhere is more of a challenge than an opportunity for refugee protection.

\section{Lawfulness of Protection Elsewhere Schemes}

The adoption and implementation of protection elsewhere policies is now so well entrenched in state practice, and ostensibly approved by the UNHCR, that one may assume it is futile to consider whether such policies are permitted at international law. However the legality of the schemes is rarely a question capable of litigation before domestic courts in light of domestic jurisdictional limits, and thus the international law arguments have rarely been canvassed and addressed in any depth. For example, in Canadian Council for Refugees v. R, Phelan J. noted that "there may be an issue of whether a Canadian law which requires a person to make their refugee claim in a country, other than the one of their choosing, is compliant with the Refugee Convention."11 However, he concluded that in the absence of other evidence, "it is presumed that Canadian law is at least compliant with the relevant Conventions." 12 It is useful at the outset to note that while the Federal Court of Appeal overturned Justice Phelan's decision to grant an application for judicial review declaring invalid sections 159.1 to 159.7 of the Immigration and Refugee Protection Regulations and the STCA, Justice Phelan's assessment of the STCA's compliance with the Refugee Convention remains relevant. ${ }^{13}$ This is because the reason for overturning Justice Phelan's decision was not that his Honour's assessment that the STCA is inconsistent with Article 33 of the Refugee Convention was incorrect as a matter of fact or law, but rather that this was not the proper question to be resolved by the Court. Justice Phelan had assumed that compliance with Article 33 (and Article 3 of the Convention Against Torture) was a condition precedent to the Governor-in-Council's exercise of its delegated authority to designate the US as a safe third country, and that since aspects of the US asylum process are inconsistent with both relevant treaties, the STCA and accompanying regulations are ultra vires. ${ }^{14}$ However the Federal Court of Appeal found that the correct inquiry was not as to whether there was actual compliance with international law, but rather only whether the Governor-in-Council had considered the factors set out in the Act (including compliance with Article 33) prior to making the designation. ${ }^{15}$ In light of the fact that the reason for overturning Justice Phelan's decision was a technical rather than substantive one, ${ }^{16}$ reference will continue to be made to his Honour's consideration of the substantive questions of actual compliance.

Turning then to the question of whether Justice Phelan was correct to raise the issue whether protection elsewhere policies are permitted at international law, the starting point must of course be the text of the Refugee Convention. ${ }^{17}$ The Refugee Convention does not explicitly authorize a transfer of a refugee or applicant for refugee status from one state party to another. Rather, authority for the legality of such transfers 
is assumed to be found in an omission in the text, namely, the lack of a right to be granted asylum. As is well understood, the Refugee Convention prohibits a state from returning a person to a state in which he or she will be exposed to persecution (the obligation of non-refoulement in Article 33). It is thus often assumed by state parties that as long as Article 33 is not violated, the state is free to transfer a refugee to a third state. Indeed, so much was assumed in the concurring opinion of Evans J.A. in the Canadian Federal Court of Appeal, where his Honour asserted in passing that the "provisions of neither the international Conventions relied on in this litigation, nor the Charter, require Canada to abstain from enacting regulations which may deter nationals of third countries in the United States from coming to the Canadian border to claim refugee protection or protection from torture." 18 This was said to be because both Article 33 of the Refugee Convention and Article 3 of the CAT "impose a negative obligation not to refoule, not a positive obligation to receive potential claimants." 19

Interestingly however an analysis of the text of the Refugee Convention reveals that it is not silent as to the circumstances in which a person may be excluded from protection on the basis that he or she is able to obtain protection elsewhere. Rather there are three situations in which a state may decline to protect a person because he or she can obtain protection elsewhere: where a person has more than one nationality, he will not satisfy the definition of refugee if "he has not availed himself of the protection of one of the countries of which he is a national" (Article $1 \mathrm{~A}(2)$ ); where a person has de facto nationality in another country the Convention "shall not apply" (Article 1E); and where a refugee acquires a new nationality and enjoys the protection of the country of new nationality the Convention "shall cease to apply" (Article 1C). Importantly, in each of these situations the refugee enjoys a level of protection in a third country greater than that provided in the Refugee Convention since in each case the refugee will enjoy equivalent protection to that enjoyed by nationals in the third state, whereas in some instances the Refugee Convention dictates a lower standard of protection for refugees than that enjoyed by nationals. ${ }^{20}$

The explicit reference to these carefully defined circumstances in which the availability of protection elsewhere can exclude a person from refugee protection might be thought to be exhaustive of the situations in which a state can decline to protect on this basis-that is, an application of the expressio unius principle. ${ }^{21}$ This may further be supported by reference to the context, object, and purpose of the Refugee Convention, matters appropriately considered under the rules of treaty interpretation, ${ }^{22}$ which could be said to support the view that the Convention requires states to engage in international co-operation to protect refugees, not deflect responsibility to other states.
The difficulty with the textual argument however is that the exclusions above all speak to the definition of a refugee and thus to who qualifies for protection. In the context of protection elsewhere practices and policies, such as the USCanada STCA, there is no suggestion that a transferred refugee applicant is excluded from protection, but rather that the claim for protection is more appropriately assessed and implemented in another state. Further, there is a contra indication in the text, in that Article 32 prohibits the expulsion of refugees other than in exceptional circumstances, but this only applies to those refugees "lawfully present" in a state's territory. ${ }^{23}$ The adoption of the concept of lawful presence was a deliberate choice and is to be distinguished from other levels of attachment such as refugees who are merely within a state party's jurisdiction or territory. ${ }^{24}$ It thus suggests that there is a period between a refugee coming within the jurisdiction of a state party and attaining the status of lawful presence during which he or she may be lawfully transferred to another state. However this conclusion does not mean that a state is untrammelled in its decision to transfer. We thus now turn to a consideration of what constraints are imposed on any decision to transfer.

\section{Refugee Rights Other than Article 33}

No state has ever asserted that there are no constraints whatever pertaining to a decision to transfer a refugee or asylum seeker to a third state; rather all states accept that at the very least Article 33 of the Refugee Convention must be respected in any decision to transfer. The content of that requirement may be subject to debate, an issue to which this article will turn below, but the fundamental relevance of Article 33 is accepted.

However what is much more controversial is whether there are any other obligations relevant to a decision to transfer a refugee. In general, states tend to assert that Article 33 is the only relevant Refugee Convention obligation, and in much of the jurisprudence it is assumed by courts, either implicitly or explicitly, that Article 33 is the only relevant consideration. In the Canadian litigation, for example, Justice Phelan concluded, following a discussion of relevant comparative case law, that "the focus of the Convention is on protection against refoulement and as long as the third party protects in practice against refoulement, other distinctions will not bar return." 25 In reaching this conclusion his Honour did not consider the relevance of other rights to this context from a principled perspective but rather relied on his Honour's view of the comparative case law. Indeed he primarily relied on Lord Bingham's judgment in Yogathas in which his Lordship stated that "the Convention is primarily directed to preventing refoulement and it is inappropriate to compare other issues between two states, such as the applicant's living 
conditions in the third country." ${ }^{26}$ However the relevance of other rights has rarely been directly argued and considered as a discrete issue in the jurisprudence and thus the persuasiveness of previous authority on this point is open to question since it is not the outcome of a considered assessment of the competing arguments but rather largely represents obiter comments in judgments otherwise primarily concerned with Article 33 as a constraint. By contrast, several expert affidavits produced in the Canadian Federal Court directly addressed this issue, representing possibly the most comprehensive elucidation of the competing arguments presented to a court to date. ${ }^{27}$ Justice Phelan's rather cursory dismissal of this important argument is particularly curious in light of this, particularly given that a number of Refugee Convention rights other than Article 33 were asserted to be at risk on return to the US, ${ }^{28}$ but perhaps is explained on the basis that under the Canadian legislation, Article 33 was the key focus of an inquiry into the validity of the Agreement. ${ }^{29}$

This raises the question as to what is the correct position as a matter of international law. The Refugee Convention in fact contains many rights other than Article 33, and it might be argued that those rights already acquired by a refugee in the sending state are relevant to determining the validity of safe third country agreements. As soon as a refugee is within the territory of a state party (regardless of whether he or she has been recognized as a refugee by the state party), he or she is entitled to the following rights: Article 3 (non-discrimination); Article 4 (freedom of religion); Article 13 (right to property); Article 16(1) (access to the courts); Article 20 (equality of access to rationing); Article 22 (right to education); Article 25 (administrative assistance); Article 27 (identity papers); Article 29 (freedom from fiscal charges); Article 31(1) (non-penalization for illegal entry or presence); Article 31(2) (freedom from constraints on freedom of movement unless necessary); Article 33 (non-refoulement); and Article 34 (consideration for naturalization). In addition, the refugee has the possibility of acquiring further rights as his or her connection with the state strengthens.

There is a strong argument that once a refugee has acquired rights in the sending state, the sending state must ensure that those rights are respected in the receiving state. ${ }^{30}$ This view has some judicial support. In overturning the "common law" doctrine of "effective protection" that had been developed by the Federal Court of Australia, in NAGV v. Minister the High Court of Australia noted that one of the problems with this doctrine was that it assumed that the only "protection obligations" which Australia owed to refugees (and thus the only obligation relevant to a decision to transfer) was that contained in Article 33. However, as the High Court noted, the Convention contains a number of other requirements including the provision of free access to courts and the right to religious freedom. ${ }^{31}$ The implication was that, as a matter of treaty interpretation, more than mere compliance with Article 33 is required in order to effect a lawful transfer. ${ }^{32}$

This is consistent with general principles of international law. As the European Court of Human Rights (ECHR) has noted, a sending state cannot avoid the obligations it has incurred under human rights treaties (in that case the European Convention on Human Rights) vis-à-vis refugees within territory simply by transferring them under the Dublin Convention; nor can it "contract out" of its legal obligations. ${ }^{33}$ This is also recognized in European Parliamentary Resolution 1569 (2007) in which states are reminded that the transfer of refugees offshore cannot "absolve a state from its responsibilities," 34 and has received support from the Assistant High Commissioner-Protection of the UNHCR. ${ }^{35}$

This reasoning applies even more strongly in the context of the Refugee Convention than in the context of general human rights treaties. The Refugee Convention's purpose is to impose obligations on states regarding a specific group of persons. While the Convention does not impose obligations on states to deliver rights to refugees in the abstract, state parties have assumed obligations to deliver rights to refugees with whom they have a connection, in some cases based on mere physical presence. If it were possible to circumvent the considerable range of obligations imposed on state parties by simply transferring a refugee to another state, this would defeat the raison dêtre of the Convention. ${ }^{36}$

Indeed, evidence suggests that rights other than non-refoulement alone are often considered critical to refugees' own idea of what amounts to "protection." ${ }^{37}$ For example, Grabska notes that in Egypt, due to the number of reservations to the Refugee Convention made by Egypt, the rights of refugees and asylum seekers are significantly constrained; so much so that "the possibility of full integration in terms of access to citizenship, civil, political, social, economic and cultural rights in Egypt for refugees is effectively ruled out." ${ }^{38}$ In her fieldwork, Grabska found that the key concern expressed by refugees was effective protection and security. Importantly, refugees view such protection "not only in terms of being free from random arrests and deportation, but also in terms of having access to basic human rights, such as the right to education, work, housing and health services." 39 Grabska quotes one Rwandan refugee: "Having a blue card is nonsense, it is like being in a prison, but even the prison is better because you are fed there. But we are not given any help so how are we expected to survive?" 40 This explains why it is that many refugees have chosen to leave Egypt and seek refuge in nearby states such as Israel; and seriously calls into question whether refugees can legally be returned to Egypt by Israel under the assumption that it is a safe third country. ${ }^{41}$ 
This has become an increasingly important issue in recent times in the context of returns to Greece by EU Member States pursuant to the Dublin Regulation. The question whether Greece can be considered a safe third country has been the subject of debate for some time, ${ }^{42}$ but has become acute since the UNHCR published a position paper in April 2008 calling for all EU Members States "to refrain from returning asylum-seekers to Greece under the Dublin Regulation until further notice." 43 In addition to concerns about the ability of returnees under Dublin to access an adequate asylum procedure in Greece, the UNHCR and other organizations have pointed to the fact that Greece has failed to implement even the minimal standards set out in the EU Reception Directive - a directive that aims to provide minimum standards for the reception of asylum seekers "that will normally suffice to ensure them a dignified standard of living." ${ }^{4}$ In 2007 the European Court of Justice found that Greece had failed to adopt Council Directive 2003/9/EC of 27 January 2003 laying down minimum standards for the reception of asylum seekers (the Reception Directive) on the basis that it failed to adopt, within the prescribed period, "the laws, regulations and administrative provisions necessary to comply" and had thus "failed to fulfil its obligations under Article 26 of that directive." 45 It is arguable that failure to implement the Reception Directive is prima facie evidence that a state is in violation of international obligations including under the Refugee Convention, the International Covenant on Civil and Political Rights (ICCPR), and the International Covenant on Economic, Social and Cultural Rights (ICECSR), given that in many respects the Reception Directive sets a lower standard than that required by these international treaties. ${ }^{46}$

As a result of these concerns, a number of EU Member States have begun halting transfers of all or some asylum seekers to Greece under the Dublin Regulation. Most relevant for present purposes is the fact that in some cases the prohibition on transfer has not been imposed due to concerns that Article 33 is at risk of violation, but rather due wholly or in part to the human rights situation for asylum seekers in Greece. For example, in May 2008 the Swedish Migration Board decided to halt the deportation of children to Greece on the basis of a real risk that children will be detained in Greece while awaiting determination of status. ${ }^{47}$ Further, during 2008 several lower administrative courts in Germany issued a temporary stay of proceedings preventing the German government from transferring asylum seekers to Greece in respect of a number of (adult) asylum seekers. In a decision of 25 April 2008 the administrative court (VG) in Giessen issued a temporary stay of proceedings for a period of six months due to the inhuman conditions for asylum seekers in Greece contrary to the Reception Directive and to the Asylum Procedures Directive. ${ }^{48}$ In another decision of 21
August 2008 the administrative court in Hamburg issued a temporary stay of proceedings on the basis that the return was not possible because of the danger of serious detriment to the asylum seeker, specifically the "conditions not conforming to human rights standards in the asylum seeker camps and the asylum proceedings that do not even approximately comply with the minimum legal standards." 49

This is consistent with the UNHCR position paper which refers to the " $[\mathrm{p}]$ roblematic reception conditions for unaccompanied minors, in particular access to health, education and welfare during the course of the asylum procedures," 50 as well as the "extremely limited reception facilities for asylum-seekers" including lack of accommodation and access to employment. ${ }^{51}$

It is unclear whether the reference to human rights in these decisions is a reference to rights contained in the Refugee Convention or other international human rights treaties, although explicit reference to the EU Reception Directive suggests that consideration of Refugee Convention rights is considered relevant. In any event, while there may be some debate concerning the extent to which other Refugee Convention rights are determinative in this inquiry, there is no question that general human rights treaties such as the ICCPR and the European Convention on Human Rights constrain a state in its ability to expel, deport, or transfer a person to another state, under a safe third country regime or otherwise. ${ }^{52}$ At the very least, a state is prohibited from removing a person where there is a real risk that his or her right to life, or right not to be subjected to torture, or to cruel, inhuman, or degrading treatment, will be violated. ${ }^{53}$

Of particular relevance to the present context, "inhuman or degrading treatment" has been interpreted so as to apply to a violation of socio-economic rights. For example, in Limbuela, the House of Lords found that the UK's policy of prohibiting asylum seekers from receiving welfare benefits when their applications were not filed "as soon as reasonably practicable" amounted to "inhuman or degrading treatment" in violation of Article 3 of the European Convention on Human Rights. As Lord Bingham explained, this was because an asylum seeker "with no means and no alternative sources of support, unable to support himself is, by the deliberate action of the state, denied shelter, food or the most basic necessities of life." 54 As to whether this action amounted to "treatment" for the purposes of Article 3, Lord Hope emphasized that the "imposition by the legislature of a regime which prohibits asylum seekers from working and further prohibits the grant to them, when they are destitute, of support amounts to positive action directed against asylum seekers and not mere inaction." 55 In the context of the ICCPR, the Human Rights Committee (HRC) has routinely found states in violation of Article 7 where they have subjected persons within 
their control, such as prisoners and detainees, to a deprivation of socio-economic rights. ${ }^{56}$

In assessing whether treatment of transferred refugees/ asylum seekers in the third state is likely to amount to degrading treatment, it is vital that regard be had to the particular vulnerability of children, especially in the area of socio-economic rights. This approach is consistent with the views of the Committee on the Rights of the Child which has emphasized that the non-refoulement obligations implied in the Convention on the Rights of the Child apply:

... irrespective of whether serious violations of those rights guaranteed under the Convention originate from non-State actors or whether such violations are directly intended or are the indirect consequence of action or inaction. The assessment of the risk of such serious violations should be conducted in an age and gender-sensitive manner and should, for example, take into account the particularly serious consequences for children of the insufficient provision of food or health services. ${ }^{57}$

Thus, where there is evidence of a real risk that asylum seekers will be subjected to such treatment on transfer under a safe third country arrangement, the sending state is prohibited from effecting such transfer under international law. This analysis therefore suggests that it is incumbent upon states to consider rights other than Article 33 of the Refugee Convention alone in assessing the legality of transfers pursuant to a protection elsewhere scheme or policy. Thus, the assumption that nothing other than Article 33 is relevant is clearly unsustainable as a matter of international law.

However, even if it were assumed that Article 33 is the only relevant constraint on a decision to transfer a refugee to a third state, it is important to note that rights violations in the third state can be relevant to an Article 33 analysis on a number of bases.

First, it may be that the conditions or treatment meted out to refugees in the third state in fact amount to persecution on the basis of race, religion, or nationality, both in the form of more traditional methods of persecution (such as violence) but particularly in the context of a violation of social and economic rights. ${ }^{58}$ This is of course very unlikely to be an issue in the context of the US-Canada STCA, but such arguments may well be made in the context of Israel's recently renewed policy of returning refugees to Egypt, in light of the situation described above. Another example is provided in the context of Indonesia- a country through which many refugees pass en route to Australia and which has been considered in the past by the Australian authorities to be a country in which a refugee may have received effective protection. ${ }^{59}$ However according to the UNHCR office in Jakarta, Indonesia cannot be considered to provide effective protection because inter alia, "[t]here is no lawful access for these persons to the labour market and thus they are not able to work legally, which obviates any adequate and dignified means of existence. There is no possibility of exercising any civil, economic, social or cultural rights." 60 This may well amount to persecution for reasons of race or nationality or even membership of a particular social group. ${ }^{61}$

Second, it might be argued that a violation of socioeconomic rights in the third country may amount to constructive refoulement, particularly if such conditions were so harsh as to give rise to a serious likelihood that refugees would risk returning home rather than tolerate the harsh conditions.

Third, the "reception conditions" afforded to refugees in the receiving state may also be relevant to the question whether the refugee is able to access a "fair and effective asylum procedure," which of course has a direct bearing on whether the third state will engage in refoulement, discussed below. Indeed, this has been noted by the UNHCR in the context of Greece, discussed above. As the UNHCR notes, "it is essential to enable asylum seekers to sustain themselves during the asylum process, not only out of respect for their rights, but also to ensure a fair and effective asylum procedure." 62 Similarly, ECRE has expressed concern that reception standards vary widely across Member States, particularly in relation to access to health care, including psychiatric assistance and facilities-an issue that may bear directly on the fairness of an adjudication procedure. ${ }^{63}$ This analysis reflects the idea of the "interdependence of rights"-a concept recognized more broadly in international human rights law and scholarship and one that needs to be more fully understood and implemented in refugee law.

This analysis leads to the conclusion that it is essential that any state wishing to implement a safe third country or protection elsewhere policy ensure that the human rights conditions in the third state are assessed as part of the decision to transfer.

\section{Article 33 of the Refugee Convention}

Even if there is no risk that a refugee will suffer persecution or other human rights violations in a third state, there are still many important issues which must be considered by the sending state in order to ensure that there is not a risk of indirect refoulement. It is well accepted that Article 33 applies to indirect refoulement as well as direct refoulement; that is, just as a state is prohibited from returning a refugee directly to a state in which he or she will be exposed to persecution, a state cannot return or transfer a refugee to a third state where it is foreseeable that the receiving state will in turn send the refugee back to a country of persecution. ${ }^{64}$ The question arises therefore as to what factors the sending state 
must consider in assessing whether indirect refoulement is foreseeable.

First, the sending state must be satisfied that the third (receiving) state has an adjudication procedure in place to assess refugee status. While the Refugee Convention does not directly impose any procedural requirements on state parties, it is well accepted that if a state is to avoid violation of a nonrefoulement obligation such as Article 33, it must institute an adequate system of status determination to enable it to ascertain whom it must protect from refoulement. ${ }^{65}$ It is beyond the scope of this paper to explore in depth the parameters of an adequate status determination system; however, the UNHCR's Assistant High Commissioner-Protection has helpfully identified the "core elements" or "hallmarks of an effective system for the determination of refugee status" as follows:

a) a single, specialised first instance body with qualified decision-makers, trained and supported with country of origin information; b) adequate resources to ensure efficiency, to identify those in need of protection quickly and to curb abuse; and c) an appeal to an authority different from and independent of that making the initial decision. ${ }^{66}$

Another UNHCR report prepared for the 2001 Global Consultations concluded that all applicants should "receive a written decision automatically," and that where a claim is rejected or declared inadmissible, "the decision should be a reasoned one." ${ }^{67}$ Further, an "asylum seeker should in principle have the right to remain on the territory of the asylum country and should not be removed, excluded or deported until a final decision has been made on the case." 68

How might a sending state assess whether the intended recipient state's refugee status determination procedures are adequate? It would seem that recognition rates might be a useful starting point. For example, the fact that the recognition rate for both refugee status and subsidiary protection in Greece was only 1.22 per cent in 2006 suggests prima facie that Greece does not comply with Article 33. ${ }^{69}$ Further, monitoring and supervision by the UNHCR might provide some helpful insight. For example, a UNHCR assessment of refugee decisions by the Greek authorities found that of the 305 decisions studied, none provided any information about the facts of the case or any detailed legal reasoning. ${ }^{70}$ Rather, they all contained a standard paragraph alleging that "it is obvious that $\mathrm{s} / \mathrm{he}$ abandoned his country in order to find a job and improve his living conditions." 71 This serves to emphasize the importance of UNHCR presence in any supposed safe third country, in that it is vital that information be available as to the quality of protection "on the ground"-an issue which in many cases may be peculiarly within the UNHCR's authority to obtain. This is not to say that UNHCR's view on whether a country is a safe third country is conclusive or can obviate the sending state's obligation to ensure that transfers comply with its own international obligations; $;^{72}$ rather it highlights the need for a method of obtaining information as to the practical reality for transferred refugees in the third state.

This, however, raises a very interesting question as to whether a refugee can be transferred to a state in which the UNHCR itself undertakes refugee status determination, particularly given that UNHCR procedure has been criticized for, inter alia, its failure to "provide applicants with specific explanations for their rejections" and its lack of independent review of first level determinations. ${ }^{73}$ This is not an academic question, given that the UNHCR is currently undertaking refugee status determination in seventy-one states, of which forty are states party to the Refugee Convention (where there are no, or inadequate, national procedures) and thirty-one are not party to the Refugee Convention. ${ }^{74}$ However as a result of sustained critique in recent years, the UNHCR has committed to improved procedures and additional training, including the publication of procedural standards in 2005, which appears to have resulted in improved refugee status determination including a higher rate of recognition of refugee claims. ${ }^{75}$ It remains an issue, however, which must be considered by a sending state, particularly where transfer will remove a refugee applicant from a highly sophisticated system of refugee status determination, as is found in countries like Australia, Canada, and New Zealand. ${ }^{76}$

Second, the third (receiving) state must guarantee access to that system for refugees in question; thus, for example, the sending state must ensure that refugees are not barred from the system by procedural rules or other impediments. The adequacy of any refugee status determination system is irrelevant if an applicant transferred under a "protection elsewhere" scheme will not have access to that process on transfer. ${ }^{77}$ This has been an issue on which a number of courts have focused. For example, in Canadian Council for Refugees v. R, Justice Phelan found that the requirement that asylum claims be filed within one year in the US (and thus that claims may be barred for failure to comply with this provision) is not consistent with the Refugee Convention, thus putting Canada at risk of a violation of Article 33 if refugees are transferred there. Similarly, in Kilic v. State of Belgium, the Belgian Conseil d'État took into account evidence that the applicant would have difficulty reopening his asylum claim in Greece in deciding to suspend the removal order made by the Belgian authorities under the Dublin Regulation. The Court held: "[ $\mathrm{t}]$ here is an important risk that the applicant is being sent to a country which does not adequately respect his right to have his asylum claim seriously considered."78 Thus, 
refugees must have a meaningful legal and factual opportunity to make a claim for protection in a third state. ${ }^{79}$

Third, the sending state must be satisfied that the receiving state interprets the Refugee Convention in a manner that respects the "true and autonomous meaning" of the definition in Article 1 of the Convention. ${ }^{80}$ In other words, if a person is likely to be recognized as a refugee in the sending state but, due to differences in interpretation, is unlikely to be so recognized in the state to which transfer is being considered, the sending state is prohibited from transferring the applicant to the third state. While minor differences will be permitted, if the differences are "significant," meaning that they will result in different treatment, then a state may not transfer a refugee to a third state. ${ }^{81}$ As Justice Phelan concluded in Canadian Council of Refugees v. R., "it should be presumed that where there is a difference in interpretation, there will be a difference in treatment." 82 This relates both to issues such as standards of proof and also to definitional issues.

In terms of the standard of proof, in Canadian Council for Refugees v. R., Justice Phelan found that the higher standard of proof applied in the US to those seeking withholding of removal, that is, "more likely than not" as opposed to "well founded fear," is not consistent with Article 33. One method by which this might be established is by considering statistics: in the Canadian challenge, the Court took note of Deborah E. Anker's evidence that the grant rate for withholding is three times lower than in respect of asylum claims. Conversely in TI the ECHR noted, in response to a challenge based on Germany's high burden of proof, that "the record of Germany in granting asylum claims gives an indication that the threshold being applied is not excessively high." 83

Turning to the substantive issues, in Canadian Council of Refugees $v$. R., Justice Phelan found that, in a number of respects, the approach of US decision makers to interpreting the refugee definition was sufficiently different to that of Canada as to suggest that it was not reasonable for Canada to consider the US a safe third country. These differences included an overly expansive view of the exclusion clauses and an unduly narrow approach to the inclusion clause especially as relevant to gender based claims. ${ }^{84}$ This careful assessment of the differences is necessary in order for the sending state to satisfy itself that there is no risk of indirect refoulement on transfer.

A recent analysis by the UNHCR of the implementation of the EU Qualification Directive reveals that there is still considerable divergence among Member States in interpreting the definition of "refugee" including differences in respect of non-state agents of persecution, ${ }^{85}$ the actors capable of providing protection, ${ }^{86}$ and the exclusion clause. ${ }^{87}$ This serves to reinforce the fact that a state that wishes to transfer even within a somewhat harmonized system must still assess whether the receiving state adopts the correct international meaning of the Refugee Convention before carrying out a transfer.

\section{Procedural Safeguards}

The analysis above has considered the factors which a sending state must take into account in assessing whether a transfer may be carried out in compliance with international law. This part now turns to consider the method by which this assessment is to be carried out by the sending state.

A state cannot make a blanket determination that a third state is safe and will deliver Convention rights for all refugees; nor can it rely on a safe third country agreement or assurances from a third state. ${ }^{88}$ Rather, refugees who are being considered for transfer must have an ability to challenge the transfer decision in their particular case. As the House of Lords has said, a state is "under a duty to inform itself of the facts and monitor the decisions made by a third country in order to satisfy itself that the third country will not send the applicant to another country otherwise in accordance with the Convention." 89 This is because in the absence of an individualized assessment, the sending state is at risk of a violation of Article 33. Even a country that generally complies with the Refugee Convention may adopt a practice or approach to interpretation which places a particular claimant at risk of refoulement; for example, the receiving state may take a narrow approach to gender claims or those from a particular group such as homosexual men and women. Accordingly, the House of Lords has held that although an "accelerated procedure" might be acceptable, the need for efficiency cannot obviate the need for a court to subject the decision to transfer a refugee to a "rigorous examination" 90 or "anxious scrutiny." 91

Indeed, that this is required by the Refugee Convention was explicitly accepted by Evans J.A. of the Federal Court of Appeal in his concurring opinion in Canadian Council of Refugees $v$. R. In explaining his finding that Phelan J's declaration of invalidity of the STCA Regulations was "not required in order to ensure that they are not applied to claimants for protection at the land border in breach of either Canada's international obligations not to refoule, or the Charter," 92 Evans J.A. explained that the Regulations are capable of being construed and applied so as to be consistent with Canada's international obligations. That is, they should be interpreted so as to ensure that "refugee claimants at the Canadian land border may not be turned back to the United States pursuant to the STCA Regulations if they can establish that, if returned, they would face a real risk of their removal by the United States to a country where they have a well founded fear of torture, or persecution on a Convention ground." 93 Further, such a risk assessment "must be made in 
respect of individual claimants, in light of the United States' law and practice at that time as it pertains to them." ${ }^{94}$ Evans J.A. further noted that a denial of access to Canada's refugee determination system "would be subject to an application for leave and for judicial review." ${ }^{55}$ Of course one may question the adequacy of such an individual determination, given that, as noted by Phelan J., the Canadian Border Services Agency (CBSA) is responsible for determining whether a person must be removed under the STCA or is eligible to be referred to the Immigration and Refugee Board (IRB) - the latter rather than the former agency being the highly specialized expert refugee status determination agency in Canada. It is not clear what expertise the CBSA has to undertake the "anxious scrutiny" of a risk of indirect refoulement required by international law. ${ }^{96}$ Although Evans J.A. notes that "[n]o doubt guidelines will be developed to assist officers in making these eligibility determinations," 97 it is by no means clear that this will amount to an adequate procedure. This is particularly so when we consider that the burden should be on the sending state to ensure that there is no foreseeable risk of refoulement-thus officers will need to be well versed in the aspects of US asylum law and practice which potentially impact on this assessment and should not expect applicants to be cognizant of the risks in their particular case.

In terms of a right of review or appeal against a decision to transfer, although available in some jurisdictions, including Canada, it is vital that the decision to transfer be suspended pending the outcome of any review or appeal in light of the potentially serious consequences for an applicant of transfer to a state which does not respect international law. This has been supported by both the UNHCR and the European Parliament following an examination of the difficulties which arise when a state does not allow for suspension of an order to transfer pending appeal, particularly when the decision to transfer is later overturned. ${ }^{98}$

\section{Post-transfer Monitoring}

The final point to note is that it is not sufficient for a state to rely on a written agreement, written assurances, or an initial assessment that transfer to a third country complies with the Refugee Convention. Rather the state must monitor the treatment of refugees in the receiving state to assess on an ongoing basis whether transfers can continue to be undertaken in accordance with international law. ${ }^{99}$ As Justice Phelan explained in Canadian Council of Refugees v. $R$, the purpose of a continuous review is to

address the fact that new matters may develop, practices and policies of the third country may shift depending on the current administration, and that opinions formed initially are not immutable and must be re-examined in the light of more current opinion and other evidence of the third country's actual, rather than, claimed compliance. ${ }^{100}$

Such ongoing assessment should focus on the application of laws and regulations to refugees in the receiving state in general, but also on individual refugees transferred under a protection elsewhere scheme. This issue has been addressed by the Human Rights Committee in the context of the implied non-refoulement obligations in the ICCPR. It has explained that when a state party expels a person to another state on the basis of assurances as to that person's treatment by the receiving state, it must "institute credible mechanisms for ensuring compliance by the receiving state with these assurances from the moment of expulsion." ${ }^{01}$ Accordingly, in Mohammed Alzery v. Sweden, the HRC held that the diplomatic assurances from Egypt relied upon by Sweden were insufficient to discharge Sweden's non-refoulement obligations, inter alia, because they "contained no mechanism for monitoring of their enforcement." ${ }^{102}$ The HRC continued:

Nor were any arrangements made outside the text of the assurances themselves which would have provided for effective implementation. The visits by the State party's ambassador and staff commenced five weeks after the return, neglecting altogether a period of maximum exposure to risk of harm. The mechanics of the visits that did take place, moreover, failed to conform to key aspects of international good practice by not insisting on private access to the detainee and inclusion of appropriate medical and forensic expertise, even after substantial allegations of ill-treatment emerged. ${ }^{103}$

This highlights the fact that the ongoing analysis of the treatment of refugees in the third (receiving) state is not just a formalistic legal one, but must take into account practical realities.

Where a state has actual or constructive knowledge of violations of the Refugee Convention or other international legal obligations by the receiving state, it can no longer, in good faith, assert that transfers can be made in accordance with international law. ${ }^{104}$ In such a case, the sending state is "disentitled from effecting any further transfers to that state under a protection elsewhere policy unless and until there is clear evidence that the breach has ceased." 105 A clear example of such a situation is the well-documented risk of indirect or chain refoulement on sending a refugee applicant to Greece under the Dublin Regulation, discussed above. Indeed, not only have the UNHCR and a number of well-respected non-government sources called for all EU Member States to place a moratorium on transfers to Greece, but the European Commission has reportedly initiated infringement proceedings against the Greek government for failing to adhere to

(C) Michelle Foster, 2008. This open-access work is licensed under a Creative Commons Attribution-NonCommercial 4.0 International License, which permits use, reproduction and distribution in any medium for non-commercial purposes, provided the original author(s) are credited and the original publication in Refuge: Canada's Journal on Refugees is cited. 
the requirements of the Dublin Regulation, in particular the requirement to substantively examine the refugee claim of a person transferred to Greece under the Dublin regulation. ${ }^{106}$ In light of this, it is difficult to understand how any state could deny that a violation of Article 33 is a foreseeable consequence of transferring a refugee applicant to Greece. However to date only Norway has halted all transfers, with other states preventing transfers only of a certain category (e.g. children) or in individual cases. ${ }^{107}$

Where, in contrast to the above situation, a state transfers a person to a third state in good faith, that is, with no actual or constructive knowledge that the third state will not respect the refugee's rights, but the third state in fact violates the refugee's rights, the Michigan Guidelines concluded that the sending state is not under a strict legal obligation to receive such refugees back into its territory and provide Convention protection. ${ }^{108}$ This is because a state is responsible for the foreseeable consequences of expulsion/deportation/removal, ${ }^{109}$ and not for any future (unforeseeable) violations of that person's rights that may later occur in the other jurisdiction. ${ }^{110}$ However, the Michigan Guidelines recommend that the sending state should, where possible, consider facilitating "the return and readmission of the refugee in question to its territory, and ensure respect for her rights there in line with the requirements of the Convention." ${ }^{111}$

\section{Conclusion}

This article has explained that, while technically permitted at international law, schemes by which states attempt to transfer responsibility over refugees are subject to stringent limitations which must be respected if transfers are to be effected lawfully. As has been displayed, these constraints are not insignificant-a point also conceded by the judiciary. In the Adan case, counsel for the Secretary of State argued that the House of Lords should not require the UK to ensure that each EU state complies with the one "true autonomous meaning" of the Refugee Convention because

[f] or the Secretary of State to be required to assess the details of the judgments of the appellate courts of other EU States, and form a judgment on whether they are consistent with the 1951 Convention, with that judgment subject to reassessment by the courts of this country by way of judicial review, would impose a complex and time consuming task that is inconsistent with, and would substantially frustrate, the objective of the 1996 Act to implement the principles in the Dublin Convention and speedily return asylum seekers to other EU States for the merits of their claims to be considered. ${ }^{112}$

Lord Steyn dismissed this, concluding that the obligation to monitor compliance of other states with the Refugee
Convention was manageable and that the "the sky will not fall in" as a result of this requirement. Further, in Yogathas, concerns about efficiency could not be said to obviate the need for rigorous scrutiny of the legality of a transfer. This does give rise to the question whether the safe third country/protection elsewhere concept is able, in conformity with international law, to achieve many of its aims. That is, if states must essentially engage in a form of refugee status determination prior to transferring an applicant, it does tend to call into question whether such schemes are capable of fulfilling their aims.

Indeed, research undertaken by ECRE led to the conclusion that "at best, the Dublin regulation adds a lengthy, cumbersome procedure to the beginning of the asylum process." 113 The European Parliament has recently noted that the "low level of effected transfers" is an indicator of the "deficiencies of the Dublin system."114 Indeed the European Parliament has called for urgent reform of the system, noting that in the absence of "a genuine common European asylum system" the Dublin system "will continue to be unfair both to asylum seekers and Member States."115

This would tend to suggest that safe third country schemes are unworkable and undermine refugee protection, and that developed countries should dedicate their considerable resources to fashioning solutions to the refugee crisis by developing policies truly concerned to address the human rights and needs of refugees.

\section{Notes}

1. It should be noted that some of the key ideas in this paper draw upon and develop further the analysis set out in Michelle Foster, "Protection Elsewhere: The Legal Implications of Requiring Refugees to Seek Protection in Another State" (2007) 28:2 Mich. J. Int'l L. 223; and "Colloquium, The Michigan Guidelines on Protection Elsewhere" (2007) 28 Mich. J. Int'l L. 207 [Michigan Guidelines].

2. Stephen H. Legomsky, "Secondary Refugee Movements and the Return of Asylum Seekers to Third Countries: The Meaning of Effective Protection" (2003) 15 Int'l J. Refugee L. 567 at $570-1$.

3. Article 4, online: $<$ http://www.cic.gc.ca/english/department /laws-policy/safe-third.asp> (date accessed: 22 January 2009).

4. Indeed, this is often the purported purpose of these schemes. For example, the Regulatory Impact and Analysis Statement accompanying the Canadian Regulations states that the STCA reflects a "widespread and growing international consensus that no refugee receiving country can, on its own, solve the refugee problems of the world. International obligations necessitate a sharing of responsibility": Canadian Council for Refugees, Canadian Council of Churches, Amnesty International, and John Doe v. R. [2007] 
F.C. J. No. 1583; 2007 FC 1262 [Canadian Council of Refugees v. R.] at para. 30 .

5. European Parliament resolution of 2 September 2008 on the evaluation of the Dublin system (2007/2262 (INI)) at paragraph M. The Resolution further notes that "a correct implementation of the Dublin Regulation may well result in the unequal distribution of responsibility for persons seeking protection, to the detriment of some Member States particularly exposed to migration flows simply on the grounds of their geographical location" (para. H); that "the Commission's evaluation reveals that, in 2005, the thirteen Member States at the borders of the Union had to deal with increasing challenges raised by the Dublin system" (para. I); and that "southern Member states are having to accept asylum applications from irregular immigrants without any assistance from third countries which are obliged to provide such assistance under international law" (para. K).

6. European Council on Refugees and Exiles (ECRE), Sharing Responsibility for Refugee Protection in Europe: Dublin Reconsidered (March 2008) at 13, online: <http://www.ecre. org/topics/asylum_in_EU/determining_responsibility > (date accessed: 16 January 2009).

7. There are now several EU directives on various aspects of refugee law: see for example Council Directive 2003/9/EC of 27 January 2003 laying down minimum standards for the reception of asylum seekers (Reception Directive); Council Directive 2004/83/EC of 29 April 2004 on minimum standards for the qualification and status of third country nationals or stateless persons as refugees or as persons who otherwise need international protection and the content of the protection granted (Qualification Directive); and Council Directive 2005/85/EC of 1 December 2005 on minimum standards on procedures in Member States for granting and withdrawing refugee status (Procedures Directive).

8. United Nations High Commissioner for Refugees, 2005 Global Refugee Trends (2006), online: <http://www.unhcr. org/statistics/> (date accessed: 22 January 2009). For similar figures in respect of Iraqi applicants, see UNHCR, Asylum in the European Union: A Study of the Implementation of the Qualification Directive, (November 2007) [UNHCR 2007] at 13, online: <http://www.unhcr.org/cgi-bin/texis/ vtx/refworld $/$ rwmain?docid $=473050632 \&$ page $=$ search $>$ (date accessed: 23 January 2009).

9. This was also recognized in the European Parliament's Resolution, supra note 5 at para. P: "whereas recognition rates of candidates for refugee status vary for certain third country nationals from approximately $0 \%$ to $90 \%$ within Member States."

10. There is a considerable body of literature concerned with the deficiencies of the US system in this context: see for example Audrey Macklin, "Disappearing Refugees: Reflections on the U.S.-Canada Safe Third Country Agreement” (2004-2005) 36 Colum. H.R.L. Rev. 365; Andrew F. Moore, "Unsafe in America: A Review of the U.S.-Canada Safe Third Country Agreement” (2007) 47 Santa Clara L.
Rev. 201; Amy K. Arnett, "One Step Forward, Two Steps Back: Women Asylum-Seekers in the United States and Canada Stand to Lose Human Rights under the Safe Third Country Agreement" (2005) 9 Lewis \& Clark L. Rev. 951; Lynn S. Hodgens, "Domestic Silence: How the U.S.-Canada Safe Third Country Agreement Brings New Urgency to the Need for Gender based Asylum Regulations” (2006) 30 Vt. L. Rev. 1045; Cara D. Cutler, "The U.S.-Canada Safe Third Country Agreement: Slamming the Door on Refugees" (2004) 11 ILSA J. Int'l \& Comp. L. 121; Sonia Akibo-Betts, "The Canada-U.S. Safe Third Country Agreement: Reinforcing Refugee Protection or Putting Refugees at Risk" (2006) J. Inst. Just. Int'l Stud. 1; and Lara Sarbit, "The Reality Beneath the Rhetoric: Probing the Discourses Surrounding the Safe Third Country Agreement" (2003) 18 J.L. \& Soc. Pol'y 138.

11. Canadian Council of Refugees v. R., supra note 4 at para. 81 . It should be noted that the arguments concerning compliance of the scheme with Canada's Charter of Rights and Freedoms will not be considered in this article.

12. Ibid.

13. It should be noted that an application seeking leave to appeal against the decision of the Federal Court of Appeal was lodged in the Canadian Supreme Court on 26 September 2008. It should also be noted that the Canadian Council for Refugees et al. have instituted a complaint in the InterAmerican Commission on Human Rights concerning the STCA, and the case has been found admissible: see John Doe et al. v. Canada Report No 121/06 2006 IACHR 240, 2006 WL 4557625 (OAS), 27 October 2006.

14. See R. v. Canadian Council for Refugees, Canadian Council of Churches, Amnesty International and John Doe [2008] F.C.J. No. 1002; 2008 FCA 229 at para. 2, per Noel J.A., with whom Richard C.J. agreed (R. v. Canadian Council for Refugees Appeal Decision).

15. Ibid. at paras. 76-80.

16. The only reference to a substantive issue is at para. 81 of Justice Noel's judgment (ibid.), where he states that, "I should add as an aside that even if "actual compliance" was a condition precedent, the conclusion reached by the Applications judge to the effect that the U.S. did not meet that requirement at the time of promulgation could not stand since it is largely based on evidence which postdates the time of the designation... ." Again however this does not call into question Justice Phelan's assessment that, at the time of judgment, the STCA did not comply with Canada's international obligations under Article 33 of the Refugee Convention and Article 3 of the Convention Against Torture (CAT).

17. Vienna Convention on the Law of Treaties, Vienna, 23 May 1968, 1155 U.N.T.S. 331, Article 31 (entered into force 27 January 1988) [VCLT].

18. R. v. Canadian Council for Refugees Appeal Decision, supra note 14 at para. 114 .

19. Ibid. 
20. See generally, James C. Hathaway, The Rights of Refuges under International Law (Cambridge: Cambridge University Press, 2005).

21. See Foster, supra note 1, 231-235.

22. VCLT, supra note 17, Article 31.

23. Hathaway, supra note 20, 659-694.

24. Ibid.

25. Canadian Council of Refugees v. R., supra note 4, para. 137 (c).

26. Regina (ex parte Yogathas) v. Secretary of State for the Home Department [2003] 1 A.C. 920, cited in Canadian Council of Refugees $v$. R., supra note 4 at para. 125.

27. Affidavits of James C. Hathaway and Kay Hailbronner, file IMM-7818-05, on file with author.

28. For example, in James C. Hathaway's affidavit, he summarizes the other expert affidavits filed in these proceedings which suggest "several laws or practices of the United States which may deprive refugees of acquired rights in relevant cases," including Article 3, Article 25, Article 31(1), Article 31(2), and Article 34: see at para. 21 of affidavit, on file with author. It should be noted that Justice Phelan did consider the issues of detention and access to counsel, but only as they related to the risk of refoulement, discussed below.

29. Secton 102(1)(a) of the Immigration and Refugee Protection Act (IRPA) provides that the Governor-in-Council may designate a country as being subject to s. 101(1)(e) (which renders a claim ineligible where a person came directly or indirectly to Canada from that country) where the country complies with Article 33 of the Refugee Convention and Article 3 of the Convention Against Torture. In deciding to designate a country, the GIC is required to consider four factors in 102(2) including (c) its human rights record, but the inquiry still appears to be focused on compliance with Article 33.

30. See Michigan Guidelines, supra note 1 at para. 8.

31. NAGV and NAGW of 2002 v. Minister for Immigration and Multicultural and Indigenous Affairs (2005) 222 CLR 161 at para. 31.

32. It should be noted that the legislation (Migration Act 1958 (Cth)) has been amended several times subsequent to this decision, so there is little interesting case law that has sought to develop this further.

33. T.I. v. The United Kingdom, 2000-III Eur. Ct. H.R. 435, 45657: "Where States establish international organizations or mutatis mutandis international agreements to pursue cooperation in certain fields of activity there may be implications for the protection of fundamental rights. It would be incompatible with the purpose and object of the [European] Convention if Contracting States were thereby absolved from their responsibility under the Convention in relation to the field of activity covered by such attribution."

34. Council of Europe: Parliamentary Assembly, Resolution 1569 (2007) on Assessment of Transit and Processing Centres as a Response to Mixed Flows of Migrants and Asylum Seekers, 1 October 2007. Res. 1569 (2007) at para. 13.6.
35. Erika Feller, "Asylum, Migration and Refugee Protection: Realities, Myths and the Promise of Things to Come" (2006) Int'l J. Refugee L. 510, 529.

36. Foster, supra note 1 at 270.

37. I am grateful to Martin Jones for his insights on this point based on a paper he presented on the panel, Protection Elsewhere: The Challenges and Opportunities for International Refugee Protection, at 12th International Metropolis Conference, Migration, Economic Growth and Social Cohesion, 8-12 October 2007, Melbourne, Australia.

38. Katarzyna Grabska, "Brothers or Poor Cousins? Rights, Policies and the Well-being of Refugees in Egypt," in Katarzyna Grabska and Lyla Mehta, eds., Forced Displacement: Why Rights Matter (Hampshire: Palgrave MacMillan 2008) at 77.

39. Ibid. at $82-3$.

40. Ibid. at 83 .

41. I note that although Israel's "hot returns" policy to Egypt was temporarily suspended in late 2007, on 23 August 2008, Israel resumed summarily returning asylum seekers to Egypt: see Amnesty International, "Israel/Egypt: At least 91 asylum-seekers and migrants from sub-Saharan Africa," AI Index: MDE 15/038/2008 03 September 2008, online: <http://www2.amnesty.se/uaonnet.nsf/7d4a30a4bfe49590c 1257011005d92fb/282a1deb281377cac12574ba00307d86/ \$FILE/51503808.pdf> (date accessed: 23 January 2009).

42. See Achilles Skordas and Nicholas Sitaropoulos, "Why Greece Is Not a Safe Host Country for Refugees” (2004) 16:1 Int'l J. Refugee L. 25.

43. UNHCR, UNHCR Position on the Return of Asylum-Seekers to Greece under the "Dublin Regulation" (15 April 2008) at 1 [UNHCR 2008], online: <http://www.unhcr.org/cgi-bin/ texis/vtx/refworld/rwmain?docid=4805bde42 $>$ (date accessed: 23 January 2009).

44. Reception Directive, supra note 7, at preambular para. (7). This has also been a concern raised by the European Parliament in its Resolution of $2^{\text {nd }}$ September on the evaluation of the Dublin system (2007/2262 (INI)) at para. E: "whereas some Member States do not apply the Reception Directive effectively, either to asylum applicants awaiting transfer to another Member State under the Dublin Regulation, or at the point of return to the Member State responsible."

45. Commission of the European Communities v. Hellenic Republic, Case C-72/06, Judgment of the Court (Fifth Chamber) of 19 April 2007.

46. This is because the Reception Directive (supra note 7) sets out minimum standards that in some respects fall below that required by international law. For example, Article 13(2) provides that "Member States shall make provisions on material reception conditions to ensure a standard of living adequate for the health of applicants and capable of ensuring their subsistence," which is arguably a lower standard than that required by Article 11 of the International Covenant on Economic, Social and Cultural Rights (ICESCR). See also Article 10 of the Reception Directive, which 
states that education can be delivered in accommodation centres and thus is only required to be delivered "under similar conditions" as nationals, which may well constitute a lower standard than that required by Article 13 of the ICESCR; and see also Article 15 of the Reception Directive which only requires states to ensure "that applicants receive the necessary health care which shall include, at least, emergency care and essential treatment of illness," compared with Article 12 of the ICESCR.

47. "Sweden halts return of child asylum seekers to Greece," TT/The Local: Sweden's news in English (7 May 2008), online: <http://www.thelocal.se/article. php?ID=11584\&print=true $>$ (date accessesd: 25 September 2008); see also Human Rights Watch, Stuck in a Revolving Door: Iraqis and other Asylum Seekers and Migrants at the Greece/Turkey Entrance to the European Union (26 November 2008) at 21, online: <http://www.hrw.org/en/ reports/2008/11/26/stuck-revolving-door?print> (date accessed: 16 January 2009).

48. VG Giessen 2 L 201/08.GI.A (25 April 2008), trans. by Anne Kallies.

49. VG Hamburg AE 368/08 (21 August 2008), trans. by Anne Kallies.

50. UNHCR 2008, supra note 43 at para. 21.

51. Ibid. at paras. 20-22.

52. See Foster, supra note 1 at $275-278$.

53. Ibid.

54. $R$ (Limbuela) v. Secretary of State for the Home Department [2006] 1 A.C. 396 at para. 7.

55. Ibid. at para. 56; see also at para. 69 per Lord Scott. It should be noted that there is related jurisprudence concerning states' implied non-refoulement obligations as they pertain to violations of socio-economic rights which apply other than in the context of refugees. In such cases, both the House of Lords and European Court of Human Rights have applied a higher test for finding that transfer is prohibited where the suffering in the country of return would be a result of that country's inability to provide basic socioeconomic rights to its citizens rather than unwillingness (see N (FC) (Appellant) v. Secretary of State for the Home Department (Respondent) [2005] UKHL 31; $N v$. The United Kingdom, European Court of Human Rights, Application No. 26565/05, Strasbourg, 27 May 2008). However the line of reasoning in Limbuela is more applicable to the present discussion since the harm faced by refugees in some "safe third countries" is clearly the result of intentional deprivation of socio-economic rights along the same lines as that at issue in Limbuela.

56. See for example C. v. Australia (900/1999), ICCPR, A/58/40 vol. II (28 October 2002) 188 (CCPR/C/76/D/900/1999); Williams v. Jamaica (609/1995), ICCPR, A/53/40 vol. II (4 November 1997) 63 (CCPR/C/61/D/609/1995); Smith and Stewart v. Jamaica (668/1995), ICCPR, A/54/40 vol. II (8 April 1999) 163 (CCPR/C/65/D/668/1995); and Rouse v. The Philippines (1089/2002), ICCPR, A/60/40 vol. II (25
July 2005) 123. For similar jurisprudence in the European Court of Human Rights see Kalashnikov v. Russia, European Court of Human Rights, Application no. 47095/99.

57. Committee on the Rights of the Child, General Comment No. 6 (2005), Treatment of Unaccompanied and Separated Children Outside Their Country of Origin, CRC/GC/2005/6 (1 September 2005) at para. 27.

58. See generally, Michelle Foster, International Refugee Law and Socio-Economic Rights: Refuge from Deprivation (Cambridge: Cambridge University Press, 2007), especially at 201-235 [Foster, Refuge from Deprivation].

59. UNHCR, UNHCR's Views on the Concept of Effective Protection as it Relates to Indonesia (2 December 2004; on file with author).

60. Ibid.

61. See generally, Foster, Refuge from Deprivation, supra note 58.

62. UNHCR 2008, supra note 43 at para. 18. A similar case was put forward in the Canadian litigation, in that the applicants asserted that the policy of detaining some asylum seekers and also the failure to provide legal counsel to refugee claimants aggravated the risk of refoulement. Justice Phelan dismissed these claims, not on the basis that they were incapable of validity in law, but rather that there was no evidential basis to support them: see Canadian Council of Refugees $v$. R., supra note 4 at paras. 228-236.

63. ECRE, supra note 6 at 18.

64. See for example, R. v. Secretary of State for the Home Department, ex parte Bugdaycay [1987] AC 514 per Lord Bridge of Harwich at 532D; R. v. Secretary of State for the Home Department, ex parte Yogathas [2002] 4 All ER 800. This was also accepted by all parties in the Canadian litigation: as Justice Phelan noted this is consistent with the Suresh decision of the Canadian Supreme Court; see Canadian Council of Refugees v. R., supra note 4 at para. 112. This was also explicitly accepted by Evans J.A. in the Federal Court of Appeal: see R. v. Canadian Council for Refugees Appeal Decision, supra note 14 at para. 123.

65. For an excellent analysis of the requirements of international law, see Gerald P. Heckman, "Canada's Refugee Status Determination System and the International Norm of Independence" (2008) 25:2 Refuge 79.

66. Erika Feller (Director, Department of International Protection, UNHCR) presentation (at the IARLJ World Conference, Judicial or Administrative Protection: Legal Systems within the Asylum Processes. Stockholm, 21 April 2005), online: <http://www.unhcr.org/admin/ADMIN/42a404cf2. html $>$ (date accessed: 30 September 2008).

67. See also Global Consultations on International Protection, Asylum Processes (Fair and Efficient Asylum Procedures), EC/GC/01/12, 31 May 2001 at 13; para. (o).

68. Ibid. at 13; para. (p).

69. UNHCR 2007, supra note 8 at 34.

70. UNHCR 2007, supra note 8 at 13-14.

71. Ibid. at 32 . 
72. I note that the relevance of the views of the UNHCR was a contentious issue in the US-Canada STCA litigation because the UNHCR had consistently stated that the US was a "safe third country." Justice Phelan was correct to undertake his Honour's own assessment of this question, as a state cannot rely on the UNHCR alone.

73. See Michael Kagan, "Frontier Justice: Legal Aid and UNHCR Refugee Status Determination in Egypt” (2006) 19:1 Journal of Refugee Studies 45 at 48.

74. Richard Towle and Richard Stainsby, "Best Practices for Refugee Status Determination: A UNHCR Global Perspective" (Paper presented at the conference Best Practices for Refugee Status Determination, Monash University and Université de Montréal, Prato Centre, Italy, 29-30 May 2008), slides on file with author.

75. See RSD Watch, "UNHCR recognition rates rise in the wake of new standards" (24 July 2008), online: <http://rsdwatch. org/index_files/Page6947.htm> (date accesssed: 1 October 2008); and RSD Watch, "Large UNHCR RSD operations will give detailed written reasons for rejection to asylumseekers denied protection" (29 September 2008), online: $<$ http://rsdwatch.org/index_files/Page7071.htm> (date accessed: 1 October 2008).

76. This is particularly an issue when the sending state has itself set up an inferior refugee status determination procedure in the third state, such as occurred in the context of Australia's "Pacific Solution": see Savitri Taylor, "Protection Elsewhere/Nowhere” (2006) 18 Int'l J. Refugee L. 283; and Susan Kneebone, "The Pacific Plan: The Provision of 'Effective Protection?”' (2006) 18 Int'l J. Refugee L. 696.

77. This has been noted as an issue of concern recently by the European Parliament in the context of the Dublin system: "whereas there is evidence that some Member States do not guarantee effective access to a procedure for determining refugee status": supra note 5 at para. D.

78. Decision No 162.040 of 28 August 2006; trans. by Nawaar Hassan.

79. Michigan Guidelines, supra note 1.

80. R. (exparte Adan) v. Secretary of State for the Home Department [2001] 2 A.C. 477; (2001) 2 W.L.R. 143 at 154 (per Lord Steyn) [Adan].

81. R. (Yogathas) v. Secretary of State for the Home Department [2003] 1 A.C. 920 at para. 9 [Yogathas].

82. Canadian Council of Refugees v. R., supra note 4 at para. 137.

83. T.I. v. The United Kingdom, supra note 33, as cited in Yogathas, supra note 81 at para. 54.

84. Canadian Council of Refugees v. R., supra note 4 at paras. 165-196 (exclusion) and paras. 197-216 (inclusion clause).

85. UNHCR 2007, supra note 8 at $42-46$.

86. Ibid. at $47-52$.

87. Ibid. at 90-95.

88. See generally Yogathas, supra note 81; and T.I. v. The United Kingdom, supra note 33.
89. Yogathas supra note 81 at para. 9 (per Lord Bingham).

90. This was emphasized recently by the UK Court of Appeal in Secretary of State for the Home Department v. Nasseri [2008] EWCA 464 where Lord Justice Laws stated "it is underlined by the need of rigorous scrutiny where an individual claims that expulsion will expose him to Article 3 ill treatment": at para. 18.

91. Yogathas, supra note 81 at para. 58 (per Lord Hope).

92. R. v. Canadian Council for Refugees Appeal Decision, supra note 14 at para. 130.

93. Ibid. at para. 123 .

94. Ibid.

95. Ibid., relying on Singh v. Minister of Employment and Immigration [1985] 1 SCR 177.

96. See Canadian Council of Refugees v. R., supra note 4 at para. 34 (Phelan J.). Once a CBSA officer decides that a person is ineligible to be referred to the IRB, a removal order is issued which is most often carried out on the same day.

97. R. v. Canadian Council for Refugees Appeal Decision, supra note 14 at para. 125.

98. See UNHCR, "The Dublin II Regulation: A UNHCR Discussion Paper" (April 2006) at 19-20; online: <http://www. unhcr.org/cgi-bin/texis/vtx/refworld/rwmain?docid=44 45fe344\&page=search $>$ (date accessed: 24 January 2009). The European Parliament has similarly asked the European Commission "to amend Articles 19 and 20 of the Dublin Regulation on 'taking charge and taking back', so as to provide applicants with an automatic suspensory right of appeal against a decision to transfer responsibility to another Member State under the Dublin Regulation.": Resolution of 2 September at para. 10; see also Legomsky, supra note 2 at 672; and ECRE, supra note 6 at 166.

99. In Yogathas, Lord Hope made it clear that integral to his decision to allow return to Germany was the fact that the Secretary of State was "able to show that he based his decision on a state of knowledge resulting from his own inquiries as to the practice in Germany and from his experience of constantly monitoring the performance by member states of their obligations in similar cases": supra note 81 at para. 47.

100. Canadian Council of Refugees v. R., supra note 4 at para. 274. These comments were made in the context of his Honour's assessment of whether the Canadian government had conducted required reviews under subsection 102(3) of the IRPA, which provides that: "The Governor-in-Council must ensure the continuing review of factors set out in subsection (2) with respect to each designated country": see ibid. at para. 265. Since there had been no such review as at the date of judgment, Phelan J. held that the GIC had failed to ensure the continuous review of the s. 102(2) factors: see at para. 275. While this finding was overturned by the Federal Court of Appeal (see R. v. Canadian Council for Refugees Appeal Decision, supra note 14 at para. 97 per Noel J.A. with whom Richard C.J. agreed; Evans J.A. not consid- 
ering), this does not detract from Phelan's explanation of the need for and importance of ongoing review.

101. UN Human Rights Committee, Concluding Observations: Sweden, at para. 79 (12)(b), UN Doc A/57/40, 57, vol I (2002).

102. Ibid. at para. 11.5 .

103. Ibid.

104. Foster, supra note 1 at 284-5.

105. Michigan Guidelines, supra note 1 at para. 15.

106. See letter from Amnesty International's EU Office to Mr. Dragutin Mate, Minister of the Interior, EU Presidency (8 March 2008), on file with author. According to ECRE, supra note 6 , details of the action against Greece have not been made public, but it is understood to relate to "the lack of legal guarantees with regard to a substantive examination of the asylum claim by Greek authorities after transfer to Greece" at 14.

107. See "A gamble with the right of asylum in Europe: Greek policy and the Dublin II regulation," Report by NOAS, Norwegian Helsinki Committee and Greek Helsinki Monitor (9 April 2008), online: <http://www.statewatch.org/ news/2008/apr/greece-dublin.pdf> (date accesssed 2 October 2008). Human Rights Watch reports that Finland has announced that it "would suspend transferring migrants to Greece unless it received written assurances from Greece that they would be fairly processed" (supra note 47 at 21); however it is unclear whether such assurances have or have not been granted.

108. See Foster, supra note 1 at 285.

109. In all of these cases, the test is said to be one of forseeability; viz: "The forseeability of the consequence would mean that there was a present violation by the State party, even though the consequence would not occur until later on": Kindler v. Canada, Human Rights Committee Communication No.
470/1991; CCPR/C/48/D/470/1991 30 July 1993 at para. 6.2 .

110. "If a person is lawfully expelled or extradited, the State party concerned will not generally have responsibility under the Covenant for any violations of that person's rights that may later occur in the other jurisdiction. In that sense a State party clearly is not required to guarantee the rights of persons within another jurisdiction': Kindler, ibid. at para. 6.2. Further, the principles of state responsibility regarding reparation do not accommodate this situation very well because they only envisage harm to states, rather than to individuals. Thus, there is little authority in international law for the position that the "injured" state in this context is required to remedy the breach by taking the person back.

111. Michigan Guidelines, supra note 1 at 285.

112. Adan, supra note 80 at 518.

113. ECRE, supra note 6 at 11.

114. European Parliament, supra note 5 at para. G.

115. Ibid. at 3 (para. 2).

Michelle Foster, S.J.D., is a Senior Lecturer and Director of the International Refugee Law Research Programme in the Institute for International Law and the Humanities at Melbourne Law School. The author would like to thank the organizers and participants at the conference Best Practices for Refugee Status Determination, Monash University and Université de Montréal, Prato Centre, Italy, 29-30 May 2008, for their helpful feedback on this paper. She would also like to thank Nawaar Hassan and Anne Kallies of Melbourne Law School for excellent research assistance, and Dr. Constantin Hruschka of the UNHCR for providing updated German case law.

(C) Michelle Foster, 2008. This open-access work is licensed under a Creative Commons Attribution-NonCommercial 4.0 International License, which permits use, reproduction and distribution in any medium for non-commercial purposes, provided the original author(s) are credited and the original publication in Refuge: Canada's Journal on Refugees is cited. 